\title{
"Fitful but Undeniable Progress" or Just the Same Old Same Old? Introduction to the Women in Sport Coaching Special Issue
}

\author{
Leslee A. Fisher \\ University of Tennessee
}

In the lead-up to the Fédération Internationale de Football Association (FIFA) Women's World Cup in France in June of 2019 , one could easily believe that long overdue progress has been made in global women's sport. In fact, Clarey (2018) summarized the year 2018 as one of ". . . fitful but undeniable progress for women in sports as they ascended to places in the executive suite, in the commentary booth, and on the awards podium they had never reached before" (para. 1). In terms of gender equity, equal prize money is now being awarded to female and male athletes in professional surfing. Equal pay is being awarded to the women's and men's national soccer team members in New Zealand and Norway; there is also movement in the United States (US) toward paying the women's national soccer team (and recent World Cup winners) the same as the men's team. In addition, at age 36, professional tennis star Serena Williams returned to competition after giving birth, reaching three Grand Slam finals, and is fighting for a better working environment for professional tennis moms (Clarey, 2018, para. 3).

However, much work is left to be done regarding gender equity - or even opportunities - for female coaches. This is particularly true for women in coaching as they negotiate systemic intersectional disempowerment in sport cultures infused with sexism. As LaVoi wrote in the forward of her edited book, Women in Sports Coaching (2016), "Sports coaching ... remains a domain where gender equity has declined or stalled, despite increasing female sport participation" (para. 1). Further, she soberly reminds us that there is almost a total absence of women coaching male athletes as well as the fact that women who coach women are now in the minority. In addition, even when female coaches are successful at the highest level of their sport (e.g., Jill Ellis, the second coach ever in World Cup history-women's or men's-to win the trophy twice as well as the most successful women's soccer coach in its history; McIntyre, 2019), there is a predictable, sexist, and homophobic backlash against them. Given that female coaches' experiences are often excluded from the telling of coaching stories, exploring how female coaches' knowledge and practices are undermined is a necessary first step toward dismantling systems of coaching oppression. In the mainstream media, many female coaches are beginning to speak out about the experience of what sociologist Smith (1990) might call "being out of step" (see Campbell, 2003, p. 17; see also Muffet McGraw interview, for example: Shapiro, 2019). Being out of step can be described as:

Occasionally, in the process of being ruled or doing ruling, someone involved has the experience of disjuncture, of being

Fisher (lfisher2@utk.edu) is with the Dept. of Kinesiology, Recreation, \& Sport Studies, University of Tennessee, Knoxville, TN. out of step. When that person's knowing is being subordinated by the organizational practices, this moment of disjuncture locates a problematic - a latent puzzle ... women have had this experience of being "out of step" in many situations . . . knowing differently was the basis for changing the conditions of women's lives. (Campbell, 2003, p. 17)

This problematic - of identifying those places where women feel out of step - can be the beginning of real change. After all, female knowers should be at the center of socially organized knowledge around women in coaching so that we can explore the outlines and delineations of the oppression.

The eight papers in this special issue of Women in Sport and Physical Activity Journal (WSPAJ) give voice to the experiences of female coaches at multiple levels of sport competition and from multiple standpoints along the pathway to, through, and out of coaching. In fact, half of the papers give voice to how identity categories intersect with ruling and oppressive systemic practices, particularly for Black female coaches. For example, Leslie Larsen and Christopher Clayton (2019) tackled issues of race and gender in exploring the career pathways to US NCAA Division I (DI) women's basketball (WBB) head coach positions. Using content analysis of the online biographies of head coaches from all 351 US DI WBB programs, they found significant differences between groups in the number of years coaching in DI women's basketball prior to receiving a first DI head coaching position. In addition, both white women and women of color had significantly more years in DI WBB coaching than white males; there was also a significant relationship between the race and gender of a coach and the highest level of playing experience and education. In another paper, George Cunningham, Na Young Ahn, Arden Anderson, and Marlene Dixon (2019) studied occupational turnover and the under-representation of women and racial minorities in sport. Through a meta-analysis of quantitative research from 10 samples and 2,802 coaches, they found that women intended to leave coaching sooner than did men. In fact, contrary to expectations, women were younger and had shorter occupational tenures than men; this suggested to Cunningham and colleagues that other factors such as women's aspirations for advancement or the macro-level barriers they encountered made coaching an unattractive option for them. In a separate paper, Matea Wasend and Nicole LaVoi (2019) asked and then answered the question: Are women coached by women more likely to become sport coaches? These two Tucker Center scholars explored the relationship between head coach gender and female collegiate athletes' entry into the coaching profession. And, Beth Clarkson, Elwyn Cox, and Richard Thelwell (2019) investigated how female coaches negotiated gender in the English soccer workplace through the construction of composite vignettes of women coaches' career experiences. By exploring the 
lived experiences of 12 women head coaches, Clarkson identified the extent to which gender influences the English football workplace. In total, these scholars point to the fact that despite calls for more research, only a limited amount of data exists exploring the ways that systemic sexist oppression in sport is perpetrated not only in systems and decision-making but in everyday practices.

It is also important to explore those places where female coaches are being supported and can experience thriving. Half of the papers in this special issue focus on these experiences. According to our authors, much of this is due to governing bodies - most notably those outside of the US, and in particular, in Canada-making explicit their ethical commitments to policies and systemic practices that advance female coaches. For example, Diane Culver, Erin Kraft, Cari Din, and Isabelle Cayer (2019) described how Canada has handled leadership development of female coaches specifically through The Alberta Women in Sport Leadership Project. This intervention is based on social learning theory and is focused on both leadership development as well as gender equity. Alixandra Krahn (2019) explores how Canadian sport policy praxis can help advance the careers of nascent female coaches. For example, Krahn analyzed national/federal Canadian sport policies to better understand their impact on the mentorship of women in coaching. Jenessa Banwell, Gretchen Kerr, and Ashley Stirling (2019) also gave us key mentorship considerations for Canadian women in coaching; through surveys with 310 current and former female coaches as well as interviews with female senior leaders in non-sport realms, Banwell suggested that women in coaching can benefit by engaging in both "sponsorship" and mentorship with male and female mentors. In addition, Justine Allen and Colleen Reid (2019) described a National Governing Body of Sport (NGB) program in Scotland entitled Women in Coaching (WiC) designed to build female coaches' competence and confidence-one she positions as, in fact, "scaffolding" their development.

Taken together, the articles in this special issue of WSPAJ provide readers with a snapshot of experiences related to women in coaching. In addition, it is clear that when governments invest in the development of women in coaching (e.g., Canada), good things for women in coaching can happen. It is our hope that readers will take the information presented here and work to change the conditions of female coaches' lives as well as expand their research frame to describe the effects of intersectional identities in greater detail. We say more about these calls for action in the final editorial by LaVoi, McGarry, and Fisher (2019) at the end of this special issue.

\section{References}

Allen, J.B., \& Reid, C. (2019). Scaffolding women coaches' development: A program to build coaches' competence and confidence. Women in Sport and Physical Activity Journal, 27, 101-109.
Banwell, J., Kerr, G., \& Stirling, A. (2019). Key considerations for advancing women in coaching. Women in Sport and Physical Activity Journal, 27, 128-135.

Campbell, M. (2003). Dorothy Smith and knowing the world we live in. The Journal of Sociology and Social Welfare, 30(1), 1-22.

Clarey, C. (December 19, 2018). For women, a year of stunning deeds and wrenching moments. Global Sports column, The New York Times. Retrieved from https://www.nytimes.com/2018/12/19/sports/ for-women-a-year-of-stunning-deeds-and-wrenching-moments.html? searchResultPosition $=4$

Clarkson, B.G., Cox, E., \& Thelwell, R.C. (2019). Negotiating gender in the English football workplace: Composite vignettes of women head coaches' experiences. Women in Sport and Physical Activity Journal, 27, 73-84.

Culver, D.M., Kraft, E., Din, C., \& Cayer, I. (2019). The Alberta Women in Sport Leadership Project: A social learning intervention for gender equity and leadership development. Women in Sport and Physical Activity Journal, 27, 110-117.

Cunningham, G.B., Ahn, N.A., Anderson, A.J., \& Dixon, M.A. (2019). Gender, coaching, and occupational turnover. Women in Sport and Physical Activity Journal, 27, 63-72.

Krahn, A.N. (2019). Sport policy praxis: Examining how Canadian sport policy practically advances the careers of nascent female coaches. Women in Sport and Physical Activity Journal, 27), 118-127.

Larsen, K.L., \& Clayton, C. (2019). Career pathways to NCAA Division I women's basketball head coach positions: Do race and gender matter?. Women in Sport and Physical Activity Journal, 27, 94-100.

LaVoi, N.M. (2016). Women in sports coaching. London, UK: Routledge.

LaVoi, N.M., McGarry, J., \& Fisher, L. (2019). Final thoughts on women in sport coaching: Fighting the war. Women in Sport and Physical Activity Journal, 27, 136-140.

McIntyre, D. (July 7, 2019). What does the future hold for USWNT coach Jill Ellis after World Cup? Yahoo Sports. Retrieved from https:// www.yahoo.com/entertainment/what-does-the-future-hold-for-uswntcoach-jill-ellis-and-her-veteran-players-172607892.html

Shapiro, A. (April 5, 2019). Notre Dame women's basketball head coach Muffet McGraw takes on gender inequality. National Public Radio's All Things Considered. Retrieved from https://www.npr.org/2019/04/ 05/710398021/notre-dame-womens-basketball-head-coach-muffetmcgraw-takes-on-gender-inequality

Smith, D.E. (1990). The ideological practice of sociology, the conceptual practices of power: A feminist sociology of knowledge. Toronto, Canada: University of Toronto Press.

Wasend, M., \& LaVoi, N.M. (2019). Are women coached by women more likely to become sport coaches? Head coach gender and female collegiate athletes' entry into the coaching profession. Women in Sport and Physical Activity Journal, 27, 85-93. 